\title{
Experimental Study of Nonequilibrium Electrodeposition of Nanostructures on Copper and Nickel for Photochemical Fuel Cell Application
}

\author{
Rajesh K. Shanmugam,, ${ }^{1}$ Bo J. Gan, ${ }^{2}$ Boya Zhang, ${ }^{1}$ Lusheng Su, ${ }^{1}$ and Yong X. Gan' \\ ${ }^{1}$ Energy Conversion Research Laboratory, Department of Mechanical, Industrial and Manufacturing Engineering, College of \\ Engineering, University of Toledo, Toledo, $\mathrm{OH} 43606$, USA \\ ${ }^{2}$ Ottawa Hills High School, 2532 Evergreen Road, Toledo, OH 43606, USA
}

Correspondence should be addressed to Yong X. Gan, yong.gan@utoledo.edu

Received 10 March 2011; Revised 10 May 2011; Accepted 8 June 2011

Academic Editor: Sakhrat Khizroev

Copyright ( $) 2011$ Rajesh K. Shanmugam et al. This is an open access article distributed under the Creative Commons Attribution License, which permits unrestricted use, distribution, and reproduction in any medium, provided the original work is properly cited.

\begin{abstract}
To increase the performance of photochemical fuel cells, nonequilibrium electrodeposition has been performed on $\mathrm{Cu}$ and $\mathrm{Ni}$ to make photosensitive anodes. Processing parameters including electrolyte concentration, and electrode potential were studied using cyclic voltammetry. Scanning electron microscopy (SEM) and X-ray Spectroscopy (EDS) were performed to understand the formation of the nanostructures during the nonequilibrium deposition of copper fractals. An increase in the deposition rate was observed with the increase in electrolyte concentration (from $0.05 \mathrm{M}$ to $1.0 \mathrm{M}$ ). Similar trend was found when the cathode potential was decreased from $-0.5 \mathrm{~V}$ to $-4.5 \mathrm{~V}$. The effect of substrate material was also examined. Porous fractal structures on copper were achieved, while the deposited material showed high density of surface cracks on nickel. The fractal structures deposited on copper electrode with the increased surface area were converted into copper oxide by oxidation in air. Such oxide samples were made into anodes for photochemical fuel cell application. We demonstrated that an increase in the magnitude of open circuit output voltage is associated with the increase in the fractal surface area under the ultraviolet irradiation test conditions. However, the electrodeposited fractals on nickel showed very limited increase in the magnitude of open circuit voltage.
\end{abstract}

\section{Introduction}

With the growing uncertainty about the availability of fossil fuels, a need to research on alternative energy sources has risen. Alternative energy resources are renewable and use the natural sources of energy, for example, solar radiation. Investing in technologies, that use alternative energy resources for high energy generation efficiency, has increased over the last two decades. Fuel cell is one of the most promising technologies in the future to generate electricity using the natural sources. One of the major efforts in fuel cell technology is to make high efficiency electrodes. Nanotechnology plays an important role in making highly active catalytic materials at electrodes.

Nanotechnology typically consists of top-down and bottom-up processing technologies. Material deposition belongs to the bottom-up one, which can be achieved in different ways, including chemical vapor deposition (CVD) [1], molecular beam epitaxy (MBE) [2], closed space vapor transport technique [3], sonoelectrochemical method [4-6], chemical bath deposition, and electrodeposition. Electrodeposition offers advantages over competing technologies such as physical and chemical vapor deposition, in that it requires simpler instrumentation and the operating conditions are easy to control [7]. With the trend toward miniaturization, electrodeposition has found more and more applications in nanomaterial processing and manufacturing $[8,9]$. It is necessary to study the structure, composition, properties, performance, and applications of different materials using electrodeposition technique.

Electrodeposition can form a material having a desirable form on a substrate. It also provides the deposit material with improved appearance and resistance to corrosion and abrasion to improve the thermoelectric characteristics of the 
material [10]. The potential application of electrodeposition is to control the thickness of materials so as to provide increased surface area for fuel cells. Understanding electrodeposition process needs the knowledge from fields such as electrochemistry, solid state physics, metallurgy, materials, and electronics [11]. The rate of electrodeposition reaction is the rate at which cations are delivered to the cathode. The three main mechanisms involved in the delivery of ions are migration, convection, and diffusion [12]. Migration refers to the movement of charge through a solution due to a potential gradient. The magnitude of the potential gradient defines the rate of reaction and usually increases with the increase in potential gradient. The velocities of ion transfer in this mechanism are very low and hence its contribution is usually neglected for mathematical simulations [13]. The thickness of the diffusive layer $\delta$ [14] is typically $200 \mu \mathrm{m}$. If under the conditions of forced convection (stirring), $\delta$ can be as low as $1 \mu \mathrm{m}$ [12].

Electrodeposition of copper is a diffusion-limited nonequilibrium process [15]. This process produces fractals [16]. Growing fractal structures through electrodeposition of $\mathrm{Cu}$ have been reported in the literature [17-22]. Characterization of fractal structures in the context of dimensions, surface roughness, and nucleation mechanisms was described in [23]. We have studied the growth of copper fractal structures on different substrates using electrodeposition technique with the intention to increase the surface area of the samples. The effects of operating conditions including electrolyte concentration, electrode potential, and electrode material on the deposition kinetics and fractal morphology were studied using cyclic voltammetry and scanning electron microscopic (SEM) analysis. The deposited samples were oxidized and tested as the anode electrode in a photochemical fuel cell.

\section{Materials and Experimental Methods}

A three-electrode system consisting of a work electrode, counter electrode, and reference electrode was used for the electrodeposition. The experiments conducted used two types of metals as working electrodes: copper and nickel under varying operating conditions of electrolyte concentration and potential. Copper and nickel were purchased from Alfa Aesar, Ward Hill, Maryland. Both metals are wires with $0.25 \mathrm{~mm}$ diameter. The length of the samples was $25 \mathrm{~mm}$. $\mathrm{Ag} / \mathrm{AgCl}$ which was used as the reference electrode was purchased from Chem Instrument, Austin, Texas. This electrode was sealed in a glass tube with $1.0 \mathrm{M}$ potassium chloride $(\mathrm{KCl})$ solution. The solution for $\mathrm{Cu}$ deposition consists of copper (II) sulphate pentahydrate (99\%) purchased from Alfa Aesar, Ward Hill, Maryland. The concentrations of the solution were $0.05 \mathrm{M}, 0.1 \mathrm{M}, 0.25 \mathrm{M}, 0.50 \mathrm{M}$, and $1.0 \mathrm{M}$. The Potentiostat used for all our experiments is the CHI400A Electrochemical Analyzer manufactured by $\mathrm{CH}$ Instruments, Inc. Austin, Texas. It basically applies a potential difference between the working electrode and reference electrode while measuring the current flow between the working electrode and auxiliary electrode. The Electrochemical Analyzer was connected to a computer for data recording. The output was in the form of both graphs and data files.

Our experiments can be divided into three main sections as described below. The first part involves the electrodeposition of $\mathrm{Cu}$ on $\mathrm{Cu}$ and $\mathrm{Ni}$ substrates. The Electrochemical Analyzer was calibrated at the required scan rate. Different low and high potentials were used in the study. The range of potential from $-4.5 \mathrm{~V}$ to $-0.05 \mathrm{~V}$ was chosen to study the effect of voltage on the electrodeposition process. During the experiment, the current data were collected by the computer and plotted against the voltage input to present the cyclic voltammograms. These cyclic voltammograms were used to analyze the current-voltage trends.

The second part of our experiments is the morphological and compositional study of the fractal structures deposited on $\mathrm{Cu}$ and $\mathrm{Ni}$ electrodes. Optical micrographs were recorded using a ProScope HR to obtain low magnification pictures of the electrodeposits. Selected samples were used for SEM analysis. The Hitachi S-4800 field emission scanning electron microscope (FESEM) and the Hitachi HD-2300 scanning tunneling electron microscope (STEM) were used to take images and perform energy dispersive X-ray spectroscopy (EDS) composition analysis.

The last part of our experiments is testing the oxidized fractals for photochemical fuel cell applications. The oxidized copper fractals were used to make the anode for breaking down the fuel, and platinum was used as the cathode for hydrogen generation. The fuel used is a mixture of $20 \%$ ethanol, $20 \%$ phosphoric acid, and $60 \%$ water. An external energy source in the form of ultraviolet rays is supplied through an ultraviolet lamp with the power of 4 watts. Open circuit potentials versus time data were recorded. The results were used to verify the effectiveness of the electrodeposited fractals for fuel cell applications.

\section{Results and Discussion}

3.1. Electrolyte Concentration Effect. In the following section, the results of cyclic voltammetry are presented to understand the electrochemical properties of the electrolyte concentration and potential effects. Then morphological and composition analysis results are provided. Finally, validation of the fractal samples as the anode electrodes for photochemical fuel cell application is given.

Cyclic voltammetry (CV) is an effective electroanalytical technique to study the basic electrochemistry of reactions. It is used to incorporate the chemistry of a reaction into a circuit and control the reaction using the voltage as the circuit parameter. The effect of electrolyte concentration on electrodeposition was studied using cyclic voltammetry. The cyclic voltammograms corresponding to $0.05 \mathrm{M}, 0.10 \mathrm{M}$, $0.25 \mathrm{M}, 0.50 \mathrm{M}$, and $1.0 \mathrm{M}$ electrolyte concentrations of $\mathrm{CuSO}_{4} \cdot 5 \mathrm{H}_{2} \mathrm{O}$ were obtained by changing the potential of the work electrode linearly between an initial value of $0 \mathrm{~V}$ and the low value of $-2.0 \mathrm{~V}$. The negative potentials were applied to facilitate the electrodeposition. The scan rate used for all the experiments was $0.1 \mathrm{~V} / \mathrm{s}$. In the graphs as will be presented below, the current density is calculated based on the original 


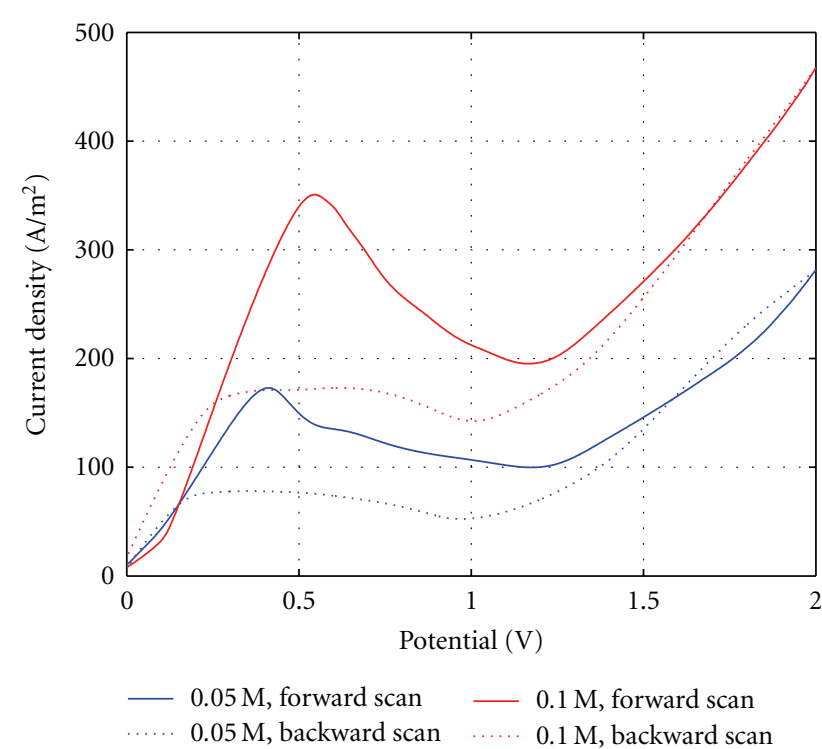

Figure 1: Cyclic voltammograms of the $0.05 \mathrm{M}$ and $0.1 \mathrm{M}$ $\mathrm{CuSO}_{4} \cdot 5 \mathrm{H}_{2} \mathrm{O}$ solutions using $\mathrm{Cu}$ as the work and auxiliary electrodes.

surface area of the cathode. The potential takes the absolute vales in the plots to be consistent with the widely accepted way in the electrochemistry field.

Figure 1 shows the cyclic voltammograms of the $0.05 \mathrm{M}$ and the $0.1 \mathrm{M} \mathrm{CuSO}_{4} \cdot 5 \mathrm{H}_{2} \mathrm{O}$ solutions using $\mathrm{Cu}$ as the work and auxiliary electrodes. The start and end electrode potentials for the experiment are $0 \mathrm{~V}$ and $-2.0 \mathrm{~V}$, respectively. In plotting the curves, the potential takes the absolute values. The graph for the $0.05 \mathrm{M}$ solution signifies two scan curves namely, forward scan curve and backward or reverse scan curve. The forward scan means that the potential changes from 0.0 to $-2.0 \mathrm{~V}$. During the reverse scan, the potential changes back from -2.0 to $0.0 \mathrm{~V}$. In the following graphs, a solid line stands for a forward scan curve, while a dotted line represents a backward scan curve. In the forward scan, an initial nonzero value of the cathode current density $\left(I_{c}\right)$ is observed due to the fact that the work electrode potential is greater than the reduction potential $\left(E_{r}\right)$. This generates the nonequilibrium condition as the driving force for copper deposition at the work electrode (cathode). For the test using the $0.05 \mathrm{M}$ solution, a peak reduction potential $\left(E_{r}\right)$ was observed at $-0.43 \mathrm{~V}$ with a cathode current density $\left(I_{c}\right)$ of $170 \mathrm{~A} / \mathrm{m}^{2}$. Followed by the peak, a gradual decrease in the current density $\left(I_{c}\right)$ was found. The decrease in the current density $\left(I_{c}\right)$ can be explained by the decrease in the concentration of the electrolyte in the diffusion layer close to the electrode surface.

The reduced copper ions in cathode region deposited at the work electrode, which accounts for the drop in the electrolyte concentration, thus the current density at the cathode. At the anode, the $\mathrm{Cu}$ metal is oxidized introducing more copper ions. In the more negatively charged potential region, the current density once again increases due to the hydrogen ion reduction. During the reverse scan, the cathode current $\left(I_{c}\right)$ decreases gradually. The shape of the reverse scan curve is very similar to the forward scan curve with some difference in the magnitude of the current density in the region close to the reduction peak. No other distinctive peaks were observed during the reverse scan. The current decreases to the original start value signifying the completion of the reaction for $\mathrm{Cu}$ deposition at the electrode surface.

Also shown in Figure 2 is the cyclic voltammogram for the test performed using the electrolyte with $0.10 \mathrm{M}$ $\mathrm{CuSO}_{4} \cdot 5 \mathrm{H}_{2} \mathrm{O}$. During the forward scan, the reduction potential $\left(E_{r}\right)$ was observed at the cathode potential of $-0.53 \mathrm{~V}$. As compared with the result of the $0.05 \mathrm{M}$ $\mathrm{CuSO}_{4} \cdot 5 \mathrm{H}_{2} \mathrm{O}$ solution, an increase in the peak cathode current density $\left(I_{c}\right)$ to $340 \mathrm{~A} / \mathrm{m}^{2}$ was observed for this higher concentration electrolyte. Such an increase of the current density at the $\mathrm{Cu}$ reduction peak is due to the increase in the molar concentration of copper ions in the electrolyte. More electron charge carriers are available in this system.

At even higher electrolyte concentration, the cyclic voltammograms show slightly different features. In Figure 2(a), the electrolyte used is $0.25 \mathrm{M} \mathrm{CuSO}_{4} \cdot 5 \mathrm{H}_{2} \mathrm{O}$ solution. During the forward scan, the reduction potential $\left(E_{r}\right)$ was observed at the same value of $-0.53 \mathrm{~V}$ with an increase in the cathode current density $\left(I_{c}\right)$ to $700 \mathrm{~A} / \mathrm{m}^{2}$. The increase of the current density at this peak is due to the further increase in the molar concentration of the electrolyte. Much more electron charge carriers are available in this system. However, a different feature is found in the reverse scan curve; a crossover occurs at a potential value of $-0.93 \mathrm{~V}$. The possible explanation is that the hydrogen reduction at the cathode in the reverse scan slowed down significantly at this potential and results in the current density drop. The potential at this point is defined as the crossover potential $\left(E_{x}\right)$.

In Figure 2(b), the electrolyte used is $0.5 \mathrm{M} \mathrm{CuSO}_{4} \cdot 5 \mathrm{H}_{2} \mathrm{O}$ solution. During the forward scan, the reduction potential $\left(E_{r}\right)$ was observed slightly shifting to a new value of $-0.7 \mathrm{~V}$ with an increase in the cathode current density $\left(I_{c}\right)$ to $1550 \mathrm{~A} / \mathrm{m}^{2}$. This increase of the current density at this peak is due to the further increase in the molar concentration of the electrolyte. The crossover occurs at a potential value of $-0.73 \mathrm{~V}$. In Figure $2(\mathrm{c})$, the electrolyte used contains $1 \mathrm{M} \mathrm{CuSO}_{4} \cdot 5 \mathrm{H}_{2} \mathrm{O}$. During the forward scan, the reduction potential $\left(E_{r}\right)$ was observed slightly shifting to a new value of $-0.9 \mathrm{~V}$ with an increase in the cathode current density $\left(I_{c}\right)$ to $3750 \mathrm{~A} / \mathrm{m}^{2}$. The drastic increase of the current density at this peak is also due to the significant increase in the molar concentration of the electrolyte. The crossover occurs at a potential value of $-1.0 \mathrm{~V}$.

To summarize the effect of concentration on the current density trend of change, the values of major characteristic points are listed in Table 1.

3.2. Electrode Potential Range Effect. The effect of electrode potential on the nonequilibrium electrodeposition process was studied by keeping the concentration of the electrolyte constant at $1.0 \mathrm{M}$. The electrolyte used for this study is copper sulphate, and $\mathrm{Cu}$ was used as the work and auxiliary electrodes. Different electrode potential ranges $(-0.5 \sim 0.0 \mathrm{~V}$, 


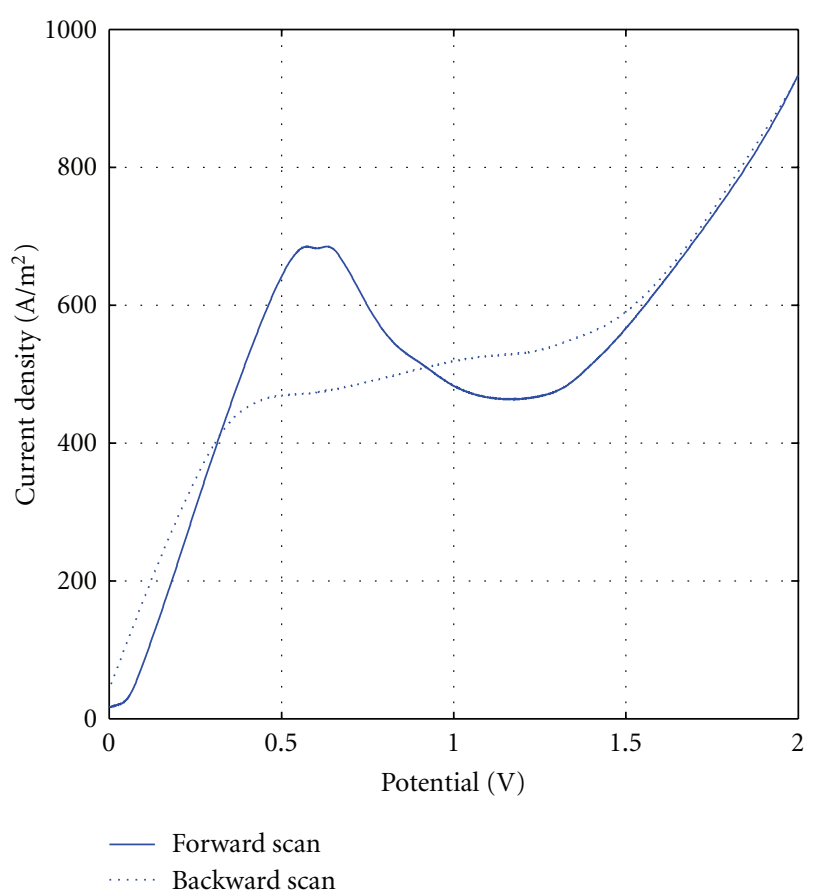

(a)

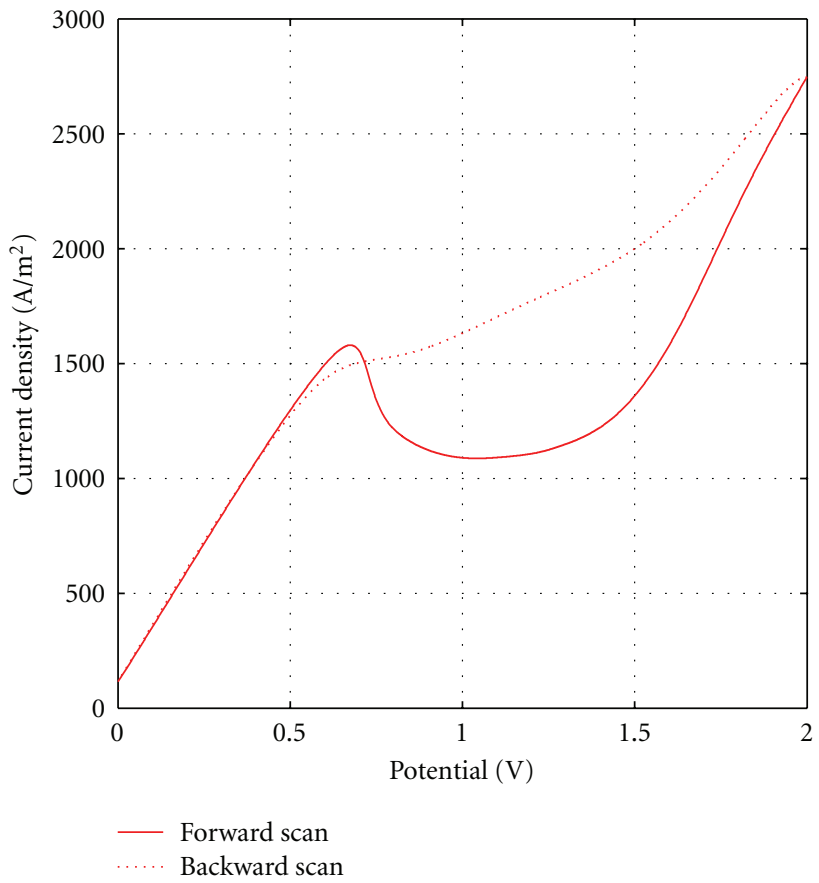

(b)

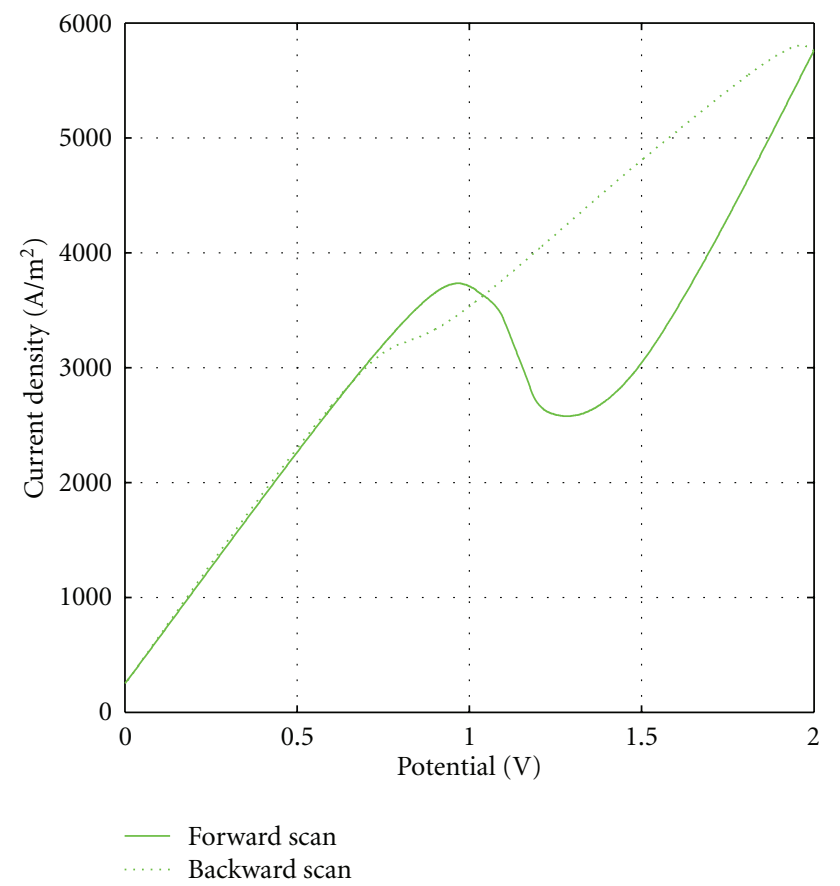

(c)

FIGURE 2: Effect of concentration on the cyclic voltammograms. (a) $0.25 \mathrm{M} \mathrm{CuSO}_{4} \cdot 5 \mathrm{H}_{2} \mathrm{O}$ solution, (b) $0.5 \mathrm{M} \mathrm{CuSO}_{4} \cdot 5 \mathrm{H}_{2} \mathrm{O}$ solution, and (c) $1.0 \mathrm{M} \mathrm{CuSO}_{4} \cdot 5 \mathrm{H}_{2} \mathrm{O}$ solution.

$-1.0 \sim 0.0 \mathrm{~V},-2.0 \sim 0.0 \mathrm{~V},-3.0 \sim 0.0 \mathrm{~V}$, and $-4.5 \sim 0.0 \mathrm{~V})$ were applied to the system using the CHI400A electrochemical analyzer. The responses of the electrolyte system to two typical electrode potentials were presented by cyclic voltammogram analysis.

As shown in Figure 3, for the cases of using the electrode potential ranges of $-3.0 \sim 0.0 \mathrm{~V}$ and $-4.0 \sim 0.0 \mathrm{~V}$, no crossover was observed between the forward scan and reverse. If the electrode potential in the range of $-3.0 \sim 0.0 \mathrm{~V}$ was applied to the system, the first reduction potential was observed to be around $-1.0 \mathrm{~V}$ as shown in Figure 3(a). The highest cathode current of $8.200 \mathrm{~A} / \mathrm{m}^{2}$ was found. For the case of electrode potential in the range from -4.5 to $0.0 \mathrm{~V}$, the first reduction peak potential occurs at $-1.0 \mathrm{~V}$. The peak cathode current 


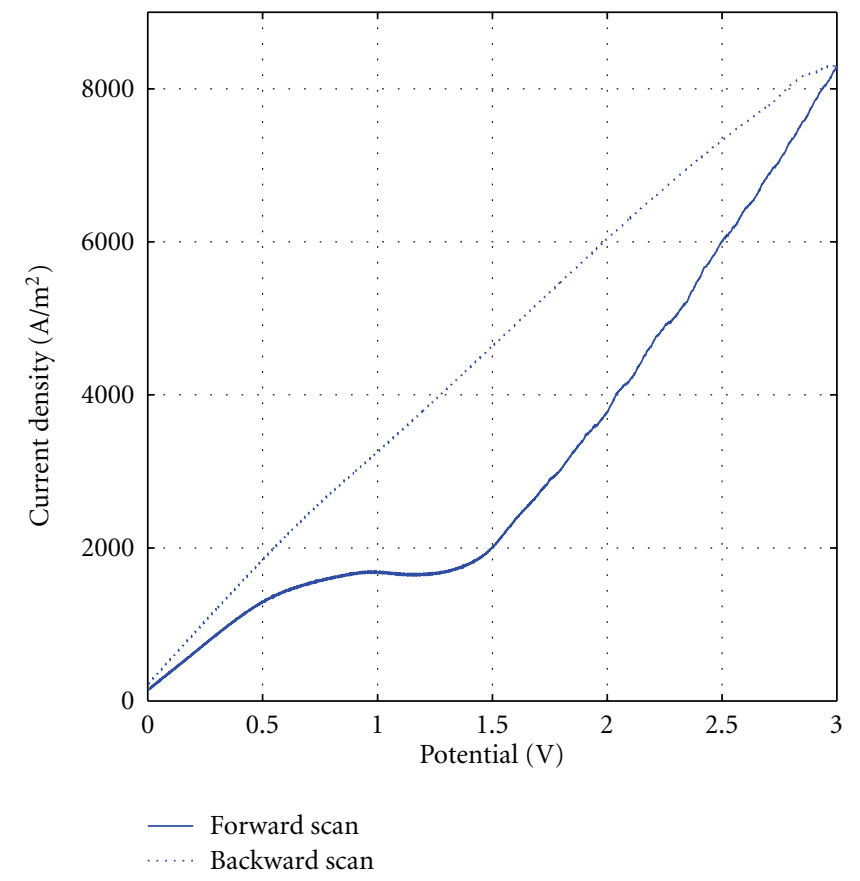

(a)

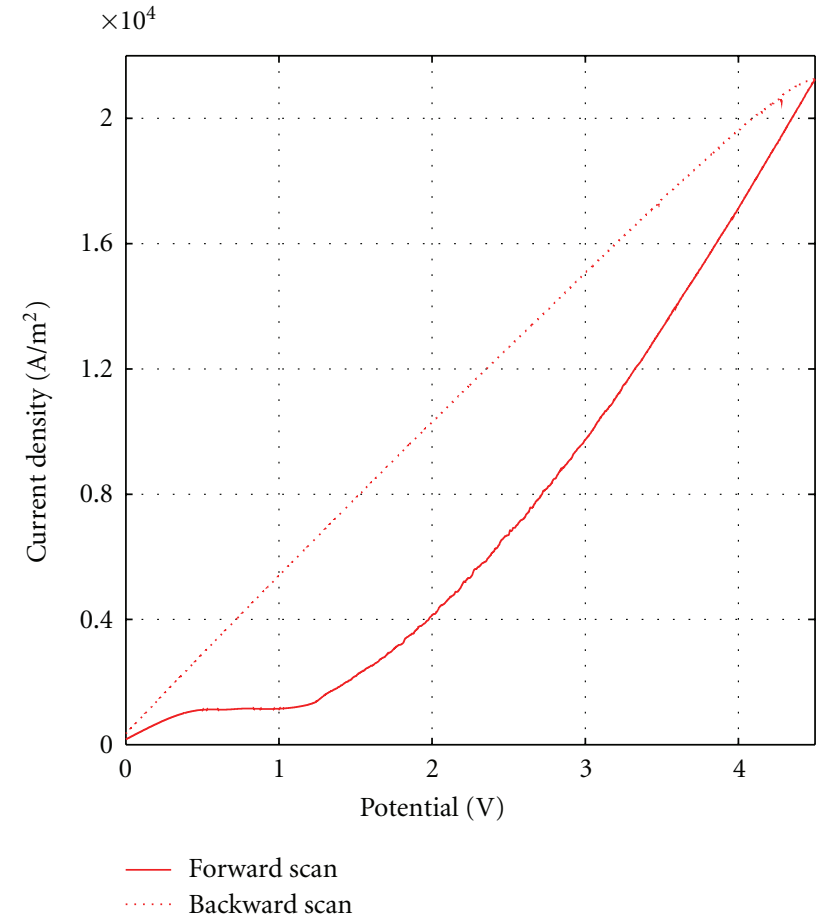

(b)

FIgURE 3: Effect of potential range on the current density in the solution containing $1 \mathrm{M} \mathrm{CuSO}_{4} \cdot 5 \mathrm{H}_{2} \mathrm{O}$ solution: (a) $0 \sim-3.0 \mathrm{~V}$ and (b) $0 \sim-4.5 \mathrm{~V}$.

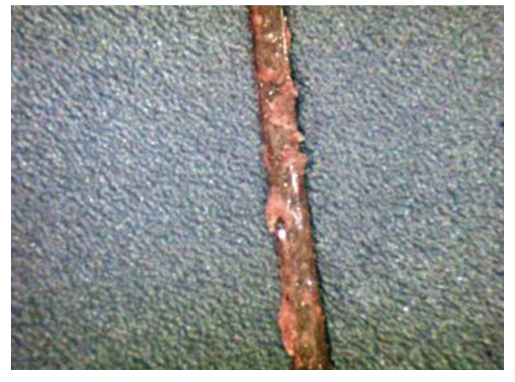

(a)

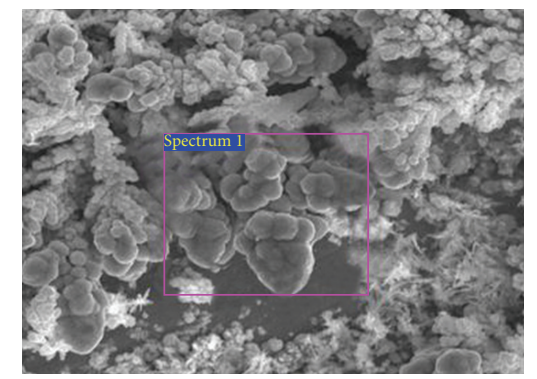

(b)

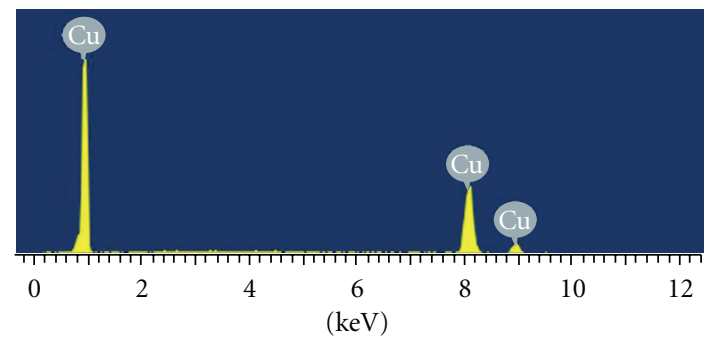

(c)

FIgURE 4: Electrodeposited $\mathrm{Cu}$ fractals using $0.25 \mathrm{M} \mathrm{CuSO}_{4} \cdot 5 \mathrm{H}_{2} \mathrm{O}$ at $-2.0 \mathrm{~V}$ : (a) Optical image, (b) SEM image, and (c) EDS spectrum.

density value is over $20.000 \mathrm{~A} / \mathrm{m}^{2}$. For both cases, no major difference in the reduction potential value was observed.

3.3. Effect of Substrate Materials. The effect of substrate electrode materials including $\mathrm{Ni}$ and $\mathrm{Cu}$ on the electrodeposition process was examined. For $0.05 \mathrm{M}$ copper sulfate electrolyte concentration, slight differences in both the magnitude of reduction potential and cathode current were observed. Nickel substrate has the $E_{r}$ value of $-0.8 \mathrm{~V}$ and $I_{c}$ value of $250 \mathrm{~A} / \mathrm{m}^{2}$, while copper substrate has the $E_{r}$ value of $-0.43 \mathrm{~V}$ and the $I_{c}$ value of $170 \mathrm{~A} / \mathrm{m}^{2}$. The crossover potential for nickel electrode occurred earlier in the reverse scan at the $E_{x}$ of $-1.15 \mathrm{~V}$. 


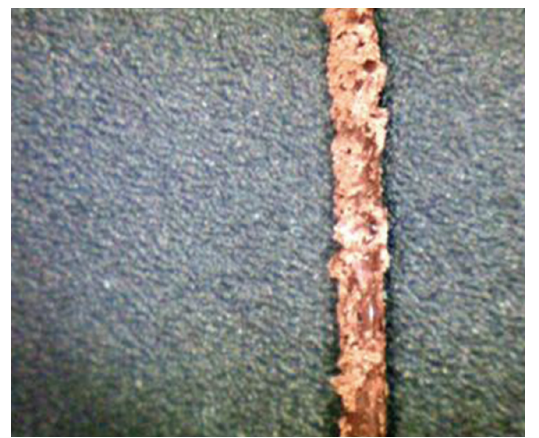

(a)

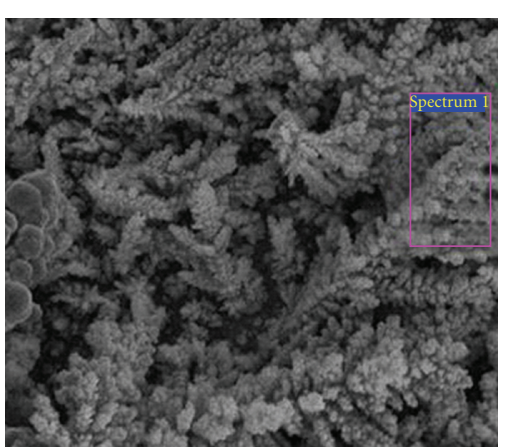

(b)

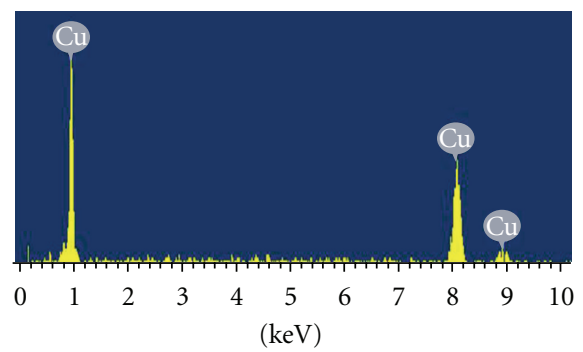

(c)

FIgUre 5: Electrodeposited $\mathrm{Cu}$ fractals using $1.0 \mathrm{M} \mathrm{CuSO}_{4} \cdot 5 \mathrm{H}_{2} \mathrm{O}$ at $-4.5 \mathrm{~V}$ : (a) Optical image, (b) SEM image, and (c) EDS spectrum.

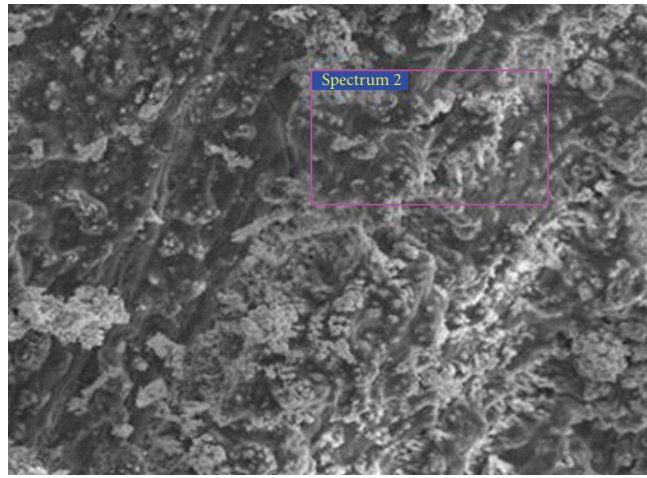

(a)

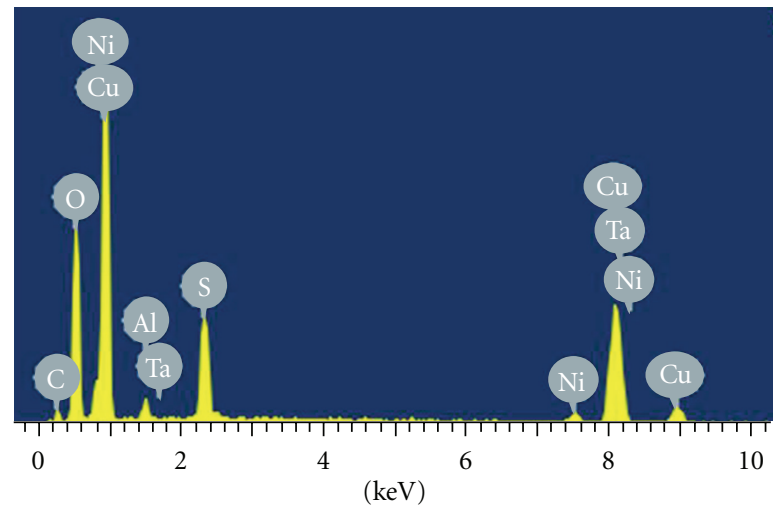

(b)

FIgURE 6: Electrodeposited copper on Ni electrode using $0.50 \mathrm{M} \mathrm{CuSO}_{4} \cdot 5 \mathrm{H}_{2} \mathrm{O}$ solution at $-2.0 \mathrm{~V}$ : (a) SEM image and (b) EDS spectrum.

TABLE 1: Reduction potential and cathode current at the peaks.

\begin{tabular}{lcc}
\hline $\begin{array}{l}\text { Electrolyte } \\
\text { concentration }\end{array}$ & $\begin{array}{c}\text { Reduction potential, } \\
E_{r}\end{array}$ & $\begin{array}{c}\text { Cathode current, } \\
I_{c}\end{array}$ \\
\hline $0.05 \mathrm{M}$ & $-0.43 \mathrm{~V}$ & $170 \mathrm{~A} / \mathrm{m}^{2}$ \\
$0.10 \mathrm{M}$ & $-0.53 \mathrm{~V}$ & $340 \mathrm{~A} / \mathrm{m}^{2}$ \\
$0.25 \mathrm{M}$ & $-0.53 \mathrm{~V}$ & $700 \mathrm{~A} / \mathrm{m}^{2}$ \\
$0.50 \mathrm{M}$ & $-0.70 \mathrm{~V}$ & $1550 \mathrm{~A} / \mathrm{m}^{2}$ \\
$1.0 \mathrm{M}$ & $-0.90 \mathrm{~V}$ & $3750 \mathrm{~A} / \mathrm{m}^{2}$ \\
\hline
\end{tabular}

No major difference was observed in the voltammograms of copper and nickel at $0.1 \mathrm{M}$ and $0.25 \mathrm{M}$ concentration electrolytes. However, the difference in the crossover potential is observed for $0.5 \mathrm{M}$ concentration case. Crossover occurred earlier in the reverse scan of the nickel electrode when compared to the copper. The value of crossover potential for copper and nickel are $-0.53 \mathrm{~V}$ and $-1.1 \mathrm{~V}$, respectively.

3.4. Morphology and Composition Analysis. Morphology and compositional analysis of the electrodeposits were carried out. The optical micrograph recorded using a ProScope HR shows the fractal image of the electrodeposits under low magnification. The SEM provides the image of the deposit under high magnification, and the X-ray mapping reveals information about the element distribution.

Three samples of electrodeposited $\mathrm{Cu}$ electrodes under different operating conditions (concentration, potential, and electrode) were analyzed. Figure 4 presents the results of characterization of $\mathrm{Cu}$ sample electrodeposited in $0.25 \mathrm{M}$ concentration of $\mathrm{CuSO}_{4} \cdot 5 \mathrm{H}_{2} \mathrm{O}$ at an electrode potential of $-2.0 \mathrm{~V}$. The nonequilibrium electrodeposition under the conditions causes uneven deposition of copper material on the electrode surface as shown in Figure 4(a). SEM image in Figure 4(b) shows the incipient growth of fractal-like structures. But the fractals are not fully formed. The EDS spectrum confirms the major element of $\mathrm{Cu}$ as revealed by the three peaks at the energy levels of $1 \mathrm{keV}, 8 \mathrm{keV}$, and $9 \mathrm{keV}$. Higher peaks were shown at $1 \mathrm{keV}$ and $8 \mathrm{keV}$, and a weaker signal was found at $9 \mathrm{keV}$.

In the case of electrodeposition of $\mathrm{Cu}$ in $1.0 \mathrm{M}$ $\mathrm{CuSO}_{4} \cdot 5 \mathrm{H}_{2} \mathrm{O}$ at $-4.5 \mathrm{~V}$, the thickness of electrodeposition increases as shown in Figure 5(a). The fractal growth is obvious under this condition with high-density dendrite structure observed in the SEM image as shown in Figure 5(b). Such a fractal structure increases the separation of the material, which is necessary for the use as an electrode in fuel cells. The EDS spectrum as shown in Figure 5(c) confirms the element of $\mathrm{Cu}$ at the fractals. 


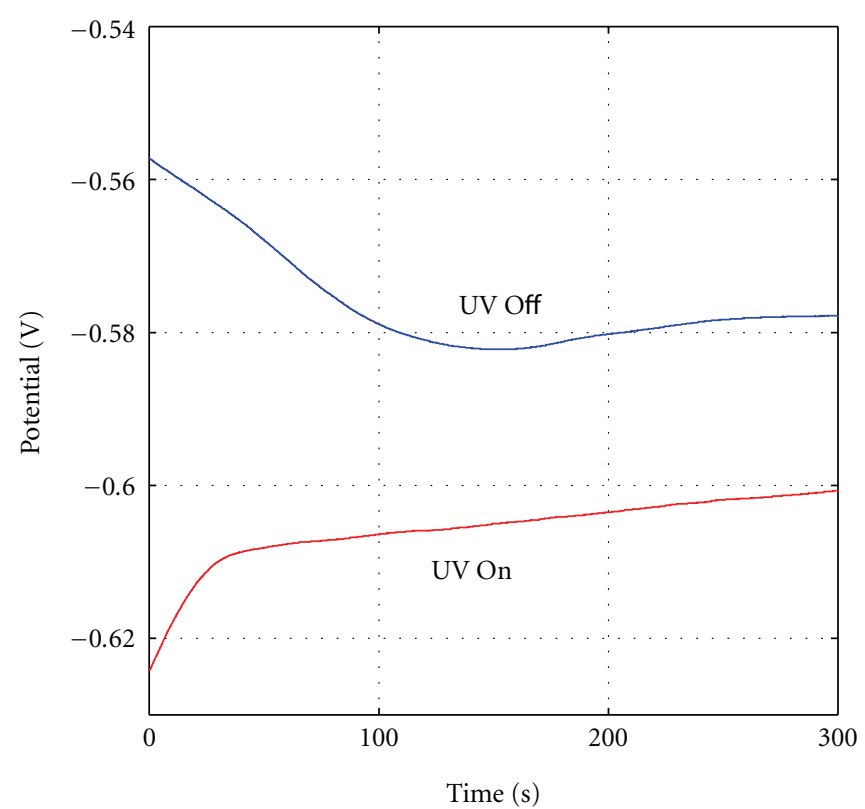

(a)

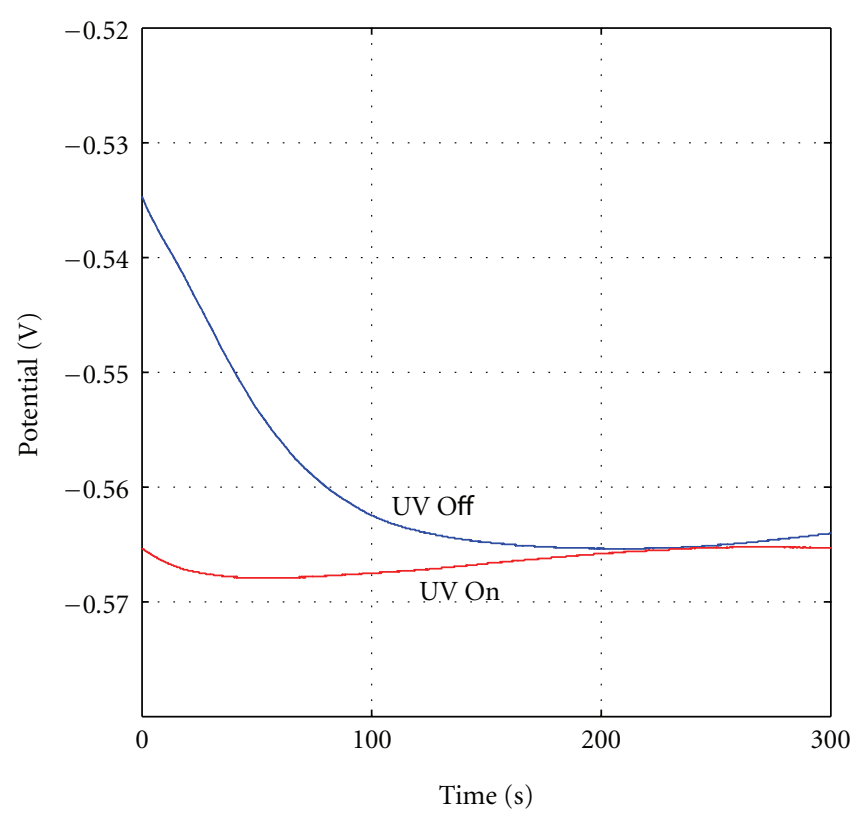

(b)

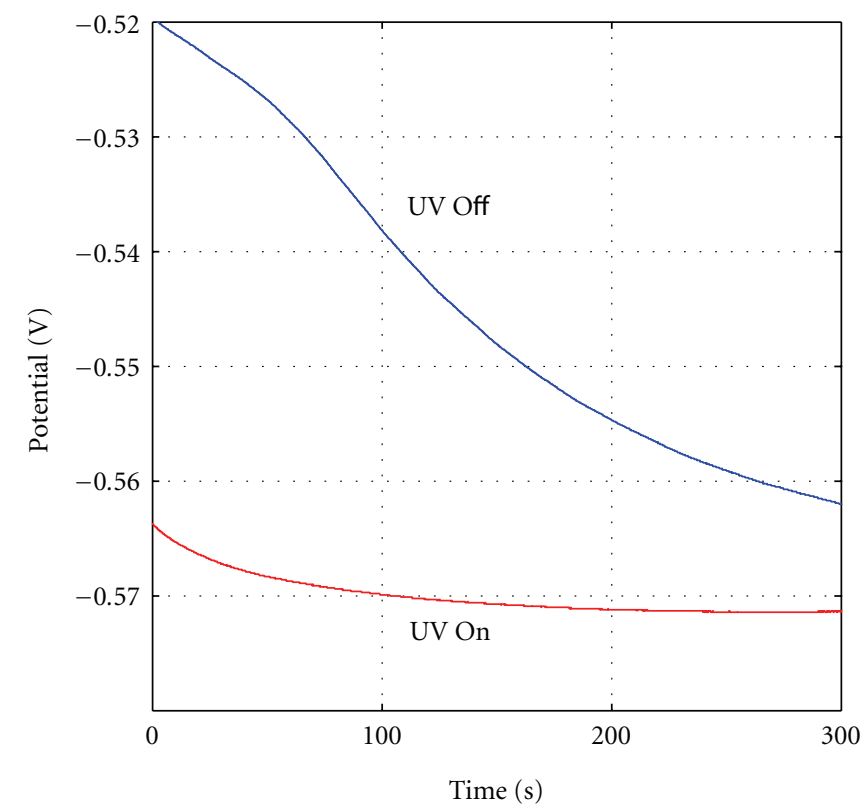

(c)

FIGURE 7: Open circuit voltage versus time of the photochemical fuel cell using different anodes: (a) $1.0 \mathrm{M} \mathrm{CuSO}_{4} \cdot 5 \mathrm{H}_{2} \mathrm{O}$ solution at $-4.5 \mathrm{~V}$ on copper, (b) $0.5 \mathrm{M} \mathrm{CuSO}_{4} \cdot 5 \mathrm{H}_{2} \mathrm{O}$ at $-2.0 \mathrm{~V}$ on copper, and (c) $0.5 \mathrm{M} \mathrm{CuSO}_{4} \cdot 5 \mathrm{H}_{2} \mathrm{O}$ at $-2.0 \mathrm{~V}$ on nickel.

We also analyzed the deposits on nickel substrate using $0.5 \mathrm{M} \mathrm{CuSO}_{4} \cdot 5 \mathrm{H}_{2} \mathrm{O}$ and the electrode potential of $-2.0 \mathrm{~V}$. Figure 6(a), the SEM micrograph, shows the surface morphology. Obviously, the fractals begun formation but are not fully developed. EDS analysis results in Figure 6(b) show that the composition is more complicated that the deposits on copper substrate because the nickel substrate contains impurities such as Ta, S, and C.

It is can be seen from the morphological analysis results in Figures 4(b), 5(b), and 6(b) that the dimension of the stem/trunk of the fractals may be at micron or submicron level. However, the size of the fine branches of these fractals is at the nanometer level. Such fine features have very high surface areas, and they are favorable for many novel applications especially for catalysis as will be presented later.

3.5. Fractals as Anode Materials for Photochemical Fuel Cell Applications. The application of the electrodeposited fractals was shown in a photochemical fuel cell. The electrolyte mixture of $20 \%$ ethanol, $20 \%$ phosphoric acid, and $60 \%$ water was used. Three cases of using different samples as the fuel cell anodes were chosen for comparison. An 
external energy source in the form of ultraviolet rays was used to sustain the breakdown of ethanol fuel to generate hydrogen and electricity. The electrons accumulated at the anodes were measured by the open circuit voltages using the electrochemical analyzer. The output data were plotted as voltage versus time curves.

Figure 7(a) shows the open circuit voltage of the fuel cell as a function of time. The fuel cell anode is the oxidized nanomaterials from the copper fractals deposited at the copper wire in $1.0 \mathrm{M} \mathrm{CuSO}_{4} \cdot 5 \mathrm{H}_{2} \mathrm{O}$ at $-4.5 \mathrm{~V}$. The cathode was a platinum wire. It is observed that there is a very clear photosensitive behavior. A UV lamp can shine on the anode. When the UV lamp was switched from OFF state to ON status, the shift in the magnitude of DC voltage was found from $-0.58 \mathrm{~V}$ to $-0.60 \mathrm{~V}$. This shift can be explained by the light sensitivity of copper oxide under UV irradiation. When the light is ON, electron ejection from the copper oxide fractals accumulated at the anode, resulting in a more negative potential.

For comparison, Figure 7(b) illustrates the open circuit voltage of the fuel cell as a function of time. The fuel cell anode is the oxidized nanomaterials from the copper fractals deposited at the copper wire in $0.5 \mathrm{M} \mathrm{CuSO}_{4} \cdot 5 \mathrm{H}_{2} \mathrm{O}$ at $-2.0 \mathrm{~V}$. It is found that the photosensitive behavior is not so evident. When the UV lamp was switched from OFF state to $\mathrm{ON}$ status, the shift in the magnitude of DC voltage was kept around $-0.565 \mathrm{~V}$.

We also tested the materials deposited on the nickel substrate. Figure 7(c) presents the test results. The fuel cell anode is the oxidized nanomaterials from the copper fractals deposited at the nickel wire in $0.5 \mathrm{M} \mathrm{CuSO}_{4} \cdot 5 \mathrm{H}_{2} \mathrm{O}$ at $-2.0 \mathrm{~V}$. From this figure, we can see that there is some photosensitive behavior. When the UV lamp was switched from OFF state to $\mathrm{ON}$ status, the shift in the magnitude of DC voltage was found from $-0.562 \mathrm{~V}$ to $-0.571 \mathrm{~V}$.

The open circuit-time results of different fractal anodes reveal the surface dependent behavior. As compared with the cases in Figures 7(b) and 7(c), Figure 7(a) shows the most significant photosensitive behavior. It is because the surface area of the electrode increases dramatically when the fractallike nanostructures are deposited on the copper electrodes. The increased surface area of the electrode results in the availability of more electrons under UV light irradiation. This could certainly result in the increased current flow through the external circuit of the fuel cell.

\section{Conclusion}

Non-equilibrium electrodeposition was performed, and the prepared fractal-like materials were used for fuel cell anodes. The following conclusions are made. As the concentration of electrolyte increases, the magnitude of reduction potential shifts to more negative region, from $-0.43 \mathrm{~V}$ to $-1.0 \mathrm{~V}$. During the deposition, as the used potential range increases, crossover between the forward and reverse scans occurs in the range from $-0.5 \mathrm{~V}$ to $-1.0 \mathrm{~V}$. Under the same deposition conditions, there exists difference in the crossover potential between $\mathrm{Cu}$ and $\mathrm{Ni}$ substrates. Fractal-like structures were observed on electrodeposited $\mathrm{Cu}$ under different operating conditions away from the equilibrium states. These conditions influence the morphology of the deposits. The shape changes from honey-comb-like structures to ferntree-like structures containing circular, oval, and spherical nanocrystals. After oxidation, the electrodeposited fractals were tested in a fuel cell environment and showed an increase in the magnitude of output DC voltage under UV irradiation. The nanostructure deposited increases the surface area of the electrode, which could improve the efficiency of the fuel cell electrodes.

\section{Acknowledgments}

This work was supported by the research startup fund, and the Faculty Summer Research Fellowship from The University of Toledo. L. Su was supported by the Doctoral Instrumentation Graduate Fellowship.

\section{References}

[1] R. Venkatasubramanian, E. Siivola, T. Colpitts, and B. O'Quinn, "Thin-film thermoelectric devices with high roomtemperature figures of merit," Nature, vol. 413, no. 6856, pp. 597-602, 2001.

[2] T. C. Harman, P. J. Taylor, D. L. Spears, and M. P. Walsh, "Thermoelectric quantum-dot superlattices with high ZT," Journal of Electronic Materials, vol. 29, no. 1, pp. L1-L4, 2000.

[3] C. Paorici and G. Attolini, "Vapour growth of bulk crystals by PVT and CVT," Progress in Crystal Growth and Characterization of Materials, vol. 48-49, no. 1-3, pp. 2-41, 2004.

[4] Q. Shen, Q. Min, J. Shi, L. Jiang, W. Hou, and J. J. Zhu, "Synthesis of stabilizer-free gold nanoparticles by pulse sonoelectrochemical method," Ultrasonics Sonochemistry, vol. 18, no. 1, pp. 231-237, 2011.

[5] F. Jia, Y. Hu, Y. Tang, and L. Zhang, "A general nonaqueous sonoelectrochemical approach to nanoporous $\mathrm{Zn}$ and $\mathrm{Ni}$ particles," Powder Technology, vol. 176, no. 2-3, pp. 130-136, 2007.

[6] C. Mahendiran, R. Ganesan, and A. Gedanken, "Sonoelectrochemical synthesis of metallic aluminum nanoparticles," European Journal of Inorganic Chemistry, no. 14, pp. 20502053, 2009.

[7] M. Datta and D. Landolt, "Fundamental aspects and applications of electrochemical microfabrication," Electrochimica Acta, vol. 45, no. 15-16, pp. 2535-2558, 2000.

[8] L. T. Romankiw, "Electroforming of electronic devices," Plating and Surface Finishing, vol. 84, no. 1, pp. 10-16, 1997.

[9] L. T. Romankiw, "A path: from electroplating through lithographic masks in electronics to LIGA in MEMS," Electrochimica Acta, vol. 42, no. 20-22, pp. 2985-3005, 1997.

[10] F. A. Lowenheim, Modern Electroplating, John Wiley \& Sons, New York, NY, USA, 1974.

[11] U. Landau, E. Yeager, and D. Kortan, "Plating-new prospects for an old art," in Electrochemistry in Industry: New Directions, Plenum Press, New York, NY, USA, 1982.

[12] N. Kanani, "Processes for the deposition of metallic coatings," Electroplating, pp. 87-140, 2004.

[13] M. Nuñez, Metal Electrodeposition, Nova Science Publishers, New York, NY. USA, 2005.

[14] V. A. Shaposhnik, V. I. Vasil'eva, and O. V. Grigorchuk, "Diffusion boundary layers during electrodialysis," Russian 
Journal of Electrochemistry, vol. 42, no. 11, pp. 1202-1207, 2006.

[15] D. Grujicic and B. Pesic, "Electrodeposition of copper: the nucleation mechanisms," Electrochimica Acta, vol. 47, no. 18, pp. 2901-2912, 2002.

[16] T. A. Witten and L. M. Sander, "Diffusion-limited aggregation, a kinetic critical phenomenon," Physical Review Letters, vol. 47, no. 19, pp. 1400-1403, 1981.

[17] J. Erlebacher, P. C. Searson, and K. Sieradzki, "Computer simulations of dense-branching patterns," Physical Review Letters, vol. 71, no. 20, pp. 3311-3314, 1993.

[18] J. Elezgaray, C. Léger, and F. Argoul, "Dense branching morphology in electrodeposition experiments: characterization and mean-field modeling," Physical Review Letters, vol. 84, no. 14, pp. 3129-3132, 2000.

[19] P. Meakin, "Diffusion-controlled deposition on fibers and surfaces," Physical Review A, vol. 27, no. 5, pp. 2616-2623, 1983.

[20] E. Ben-Jacob, G. Deutscher, P. Garik, N. D. Goldenfeld, and Y. Lareah, "Formation of a dense branching morphology in interfacial growth," Physical Review Letters, vol. 57, no. 15, pp. 1903-1906, 1986.

[21] T. Nagatani and F. Sagués, "Morphological changes in convection-diffusion-limited deposition," Physical Review A, vol. 43, no. 6, pp. 2970-2976, 1991.

[22] F. Argoul, A. Arneodo, G. Grasseau, and H. L. Swinney, "Selfsimilarity of diffusion-limited aggregates and electrodeposition clusters," Physical Review Letters, vol. 61, no. 22, pp. 25582561, 1988.

[23] L. Sun, C. L. Chien, and P. C. Searson, "Fabrication of nanoporous nickel by electrochemical dealloying," Chemistry of Materials, vol. 16, no. 16, pp. 3125-3129, 2004. 

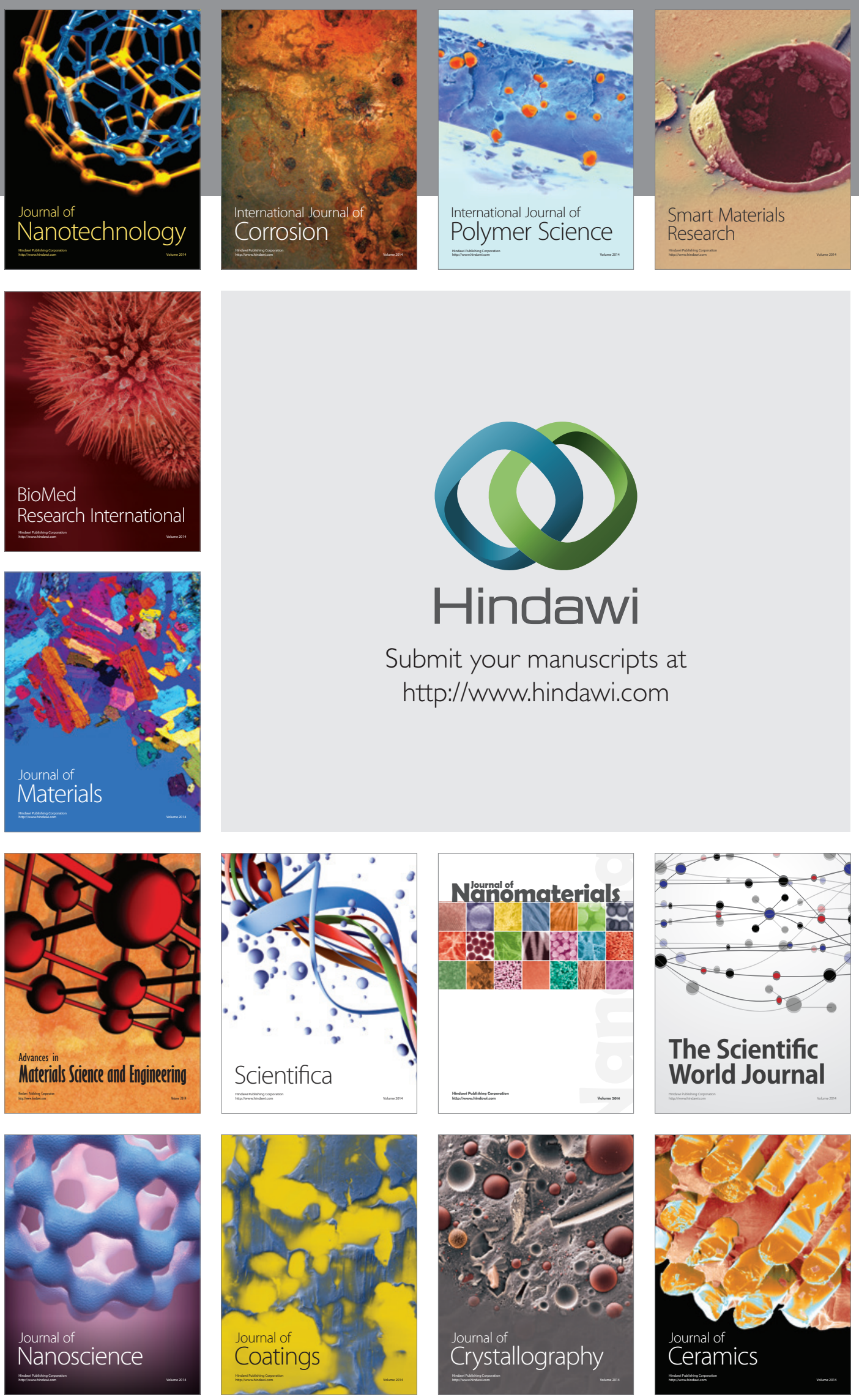

The Scientific World Journal

Submit your manuscripts at

http://www.hindawi.com

\section{World Journal}

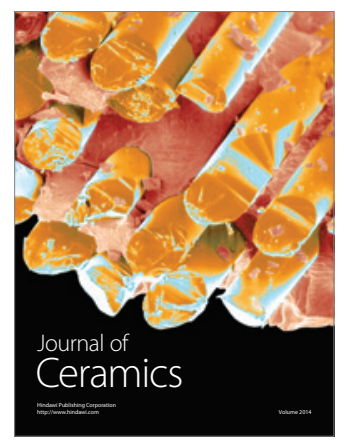

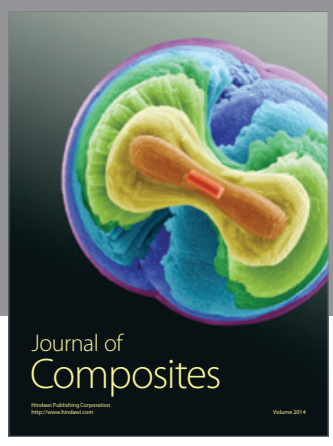
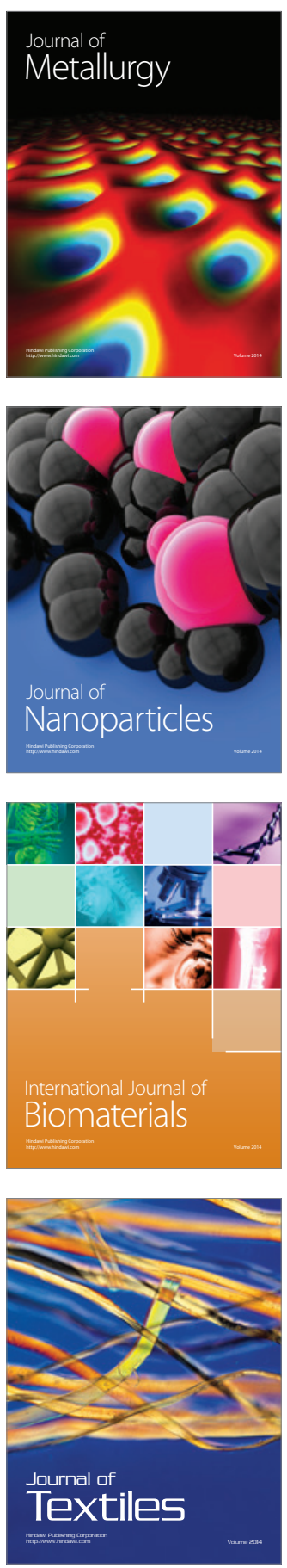